\section{Container Planting in Ontario ${ }^{1}$}

\author{
By GEORGE E. MacKINNON
}

Ontario Department of Lands and Forests

Toronto, Ontario

ODC 232-429 (713)

\begin{abstract}
"Although it is too early to assess the full possibilities of the tubed seedling program, we feel that this method of regenerating forest land will become a useful addition to other regen. eration techniques."
\end{abstract}

\begin{abstract}
An average of 17 million tubed seedlings were planted annually in the Province of Ontario from 1966 to 1969 . Plans call for increasing the programme to an estimated 20 million tubed seedlings in 1971.

Tubed seedlings provide a supply of seedling stock, which can be planted during the summer months, making the best use of available labour supply. Other advantages are ease of planting on shallow-soiled sites, ease of handling, low planting costs, and flexibility provided by production of seedlings on short notice to meet immediate needs. The principal species grown are black spruce, white spruce, jack pine, red pine and white pine. The ground is generally site prepared prior to planting by mechanical scarification or prescribed burning. Planting is carried out at average spacing of 1,000 trees per acre. Survival figures of recent planting, after one year, indicate survival comparable to that of standard bare-rooted nursery stock.
\end{abstract}

\section{La plantation en tubes en Ontario}

\section{Résumé}

De 1966 à 1969, on a planté chaque année en Ontario quelque 17 millions de plants en tubes. On prévoit intensifier le programme de façon à atteindre environ 20 millions de plants en 1971.

Les plants en tubes peuvent être mis en terre au cours des mois d'été permettant ainsi de tirer le meilleur parti de la main-d'oeuvre disponible.

${ }^{1}$ This paper was prepared for the Canadian Council of Resource Ministers as background material for the Forestry Seminar, held in Winnipeg, November 25-27, 1970.

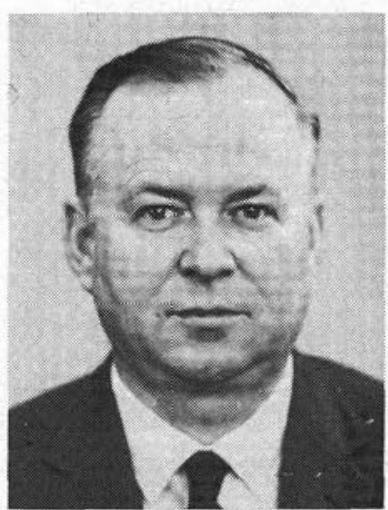

Ils sont également plus faciles à planter dans les endroits où le sol est peu profond; les plants sont plus faciles à manier, les coûts de plantation sont moins élevés, et cette méthode permet une grande souplesse étant donné qu'il est possible de produire rapidement des semis pour répondre à des besoins immédiats. Les principales essences cultivées sont l'épinette noire, l'épinette blanche, le pin gris, le pin rouge et le pin blanc. Le sol est habituellement préparé avant la plantation par un scarificateur mécanique ou par un feu contrôlé. On plante habituellement 1000 arbres à l'acre. Le taux de survie des plantations récentes, après une année, se compare à celui des plants de pépinière dont la racine est découverte.

\section{Purpose and Size of Programme}

Container planting in the form of tubed seedlings was developed mainly to provide a supply of seeddling stock, which could be planted during the summer months, thus making the best use of available labour supply. Tubed seedlings also facilitate the planting of shallow-soiled sites, where planting of bare-rooted stock is very difficult. Other advantages are ease of handling, low planting costs, and flexibility provided by production of seedlings on short notice to meet immediate needs.

The Province of Ontario commenced planting tubed seedlings on an operational basis in 1966, with approximately 17 million seedlings being planted. In 1967 and 1968, approximately 19 million seedlings were planted yearly, and in 1969 approximately 13 million seedlings were planted, with about 4 million seedlings being over-wintered in the trays for outplanting in 1970. 
In 1970, plans presently call for production of 19 million seedlings, with 12 million seedlings being planted, and 11 million trees being carried over winter for planting in 1971. The total planting programis expected to be approximately 20 million seeddlings in 1971, reforesting an area of 20,000 acres.

\section{Tubed Seedling Production}

The principal species grown are black spruce, white spruce, jack pine, red pine and white pine. The seedlings are grown in temporary portable steel frame plastic covered greenhouses, located at 14 different locations across the Province. One District last year utilized the services of a commercial greenhouse with excellent results. Construction of 4 permanent type greenhouses is planned for 1970.

An organic soil, which may be described as a peaty muck is used as a growing medium. The soil should be well screened and moist. A coarse clean silica sand is used as a seed cover after seeding. The seed is graded as to size with the middle size class seed being utilized to provide more even germination and growth. Seed of the highest viability possible is selected.

A balanced fertilizer is applied in liquid form at regular intervals, with additional watering being carried out as required. Captan is used to control damping off. Temperatures are controlled by a combination of air vents, shading, and watering as required. The buildings are heated by oil fired space heaters and electric fans to promote air circulation.

The tubes used are composed of high impact styrene, white in colour, 3 inches long by $9 / 16$ inch in diameter, with a slit down one side. Although this tube has been found to be satisfactory, experiments are presently being carried out with plastic tubes of larger diameters and lengths, as well as Kraft paper tubes, and the con-wed plastic perforated tube, to determine their possibilities and compare performance.

The seedlings are grown to a minimum height of 2 inches and preferably 3 to 5 inches above the tube prior to planting, which requires a growing period of 2 to 4 months depending on species and growing conditions. The roots should extend to the bottom of the tube, so they are ready to penetrate the subsoil immediately after planting. The use of copper paint on the bottom of the trays makes it possible to develop an excellent root system without the roots spiralling or interlocking on the tray bottoms. The development of a healthy well-balanced seedling before planting is essential to the success of the programme.

Indications are now that it will be necessary to over-winter approximately $50 \%$ of the production each year, especially in the case of the spruces, in order to get the best results in terms of subsequent growth and survival. Over-wintering may be carried out easily with excellent survival of the stock.

Up till the present time, all soil loading and seeding operations have been carried out by hand, but an automatic tube loading machine, installed in a trailer, is presently undergoing operational field trials. This machine is designed to produce approximately 500,000 loaded tubes per day. The cost of production is approximately $\$ 16.00$ per thousand but reductions may be achieved by utilizing centralized production centres and use of automated equipment.

\section{Planting Procedure}

The planting is carried out entirely on Crown lands and mainly on licenced cut-over areas, at an average rate of approximately 1,000 trees per acre. The ground is generally site prepared prior to planting by use of scarification equipment such as spiked drums towed behind a D7-E or D-8 bulldozer, or in some cases site preparation is carried out by prescribed burning. Planting is also carried out on natural burn areas, where sufficient duff and surface litter has been removed.

Tubed seedlings are planted in the summer months by hand using planting hoes or canes equipped with a dibble. The tube is inserted into the hole by hand with the top of the tube almost flush with the ground. To minimize the danger of frost heaving, the tubes are planted whenever possible in the organic layer, with only the bottom of the tube in or near the mineral soil. Planting in bare mineral soil is not recommended.

The selection of the best microclimate possible, when planting, is essential to maximum survival and growth of the seedlings. The microclimate can be modified by furrowing or scarifying to obtain a more favourable heat balance at the ground surface. Planting should be carried out on the North East side of rocks, boulders, shrubs or trees, which will prevent surface temperatures from reaching lethal proportions. This is particularly important in burntover areas, where surface temperatures will be exsurveys indicate that when mortality occurs, it tremely high on a hot summer day. Preliminary surveys indicate that when mortality occurs, it often occurs in the first two weeks after planting out. In many cases, it is apparently caused by dessication. For this reason, it is important that as many precautions as possible be taken to ensure that moisture will be available to the seedling for several weeks after planting. The planting of tubes flush with the ground also improves the moisture

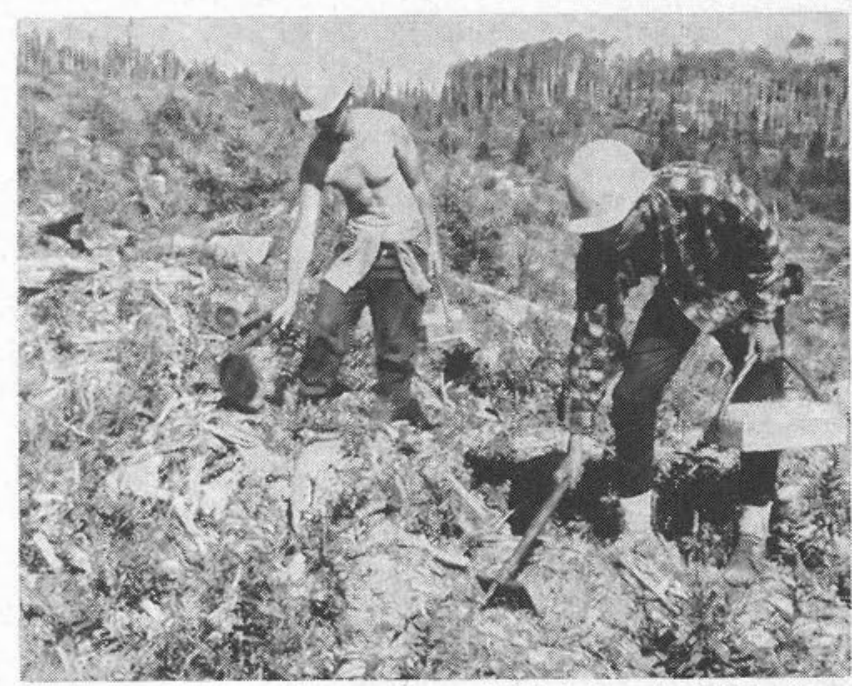

Planting tubed seedlings with a dibbled shovel, White River District, July 1966.

December 1970 The Forestry Chronicle 
retaining capacity of the tubes and gives better survival results.

Tubed seedling planting should be completed by August 15th if possible, in order to give the seedlings time to become satisfactorily established before the arrival of the fall frosts.

Since planting may be carried out in the summer months, the normal work force may be augmented by high-school and university students. These students have been found to be a very satisfactory source of seasonal labour. The ability to plant in mid-summer after the normal nursery stock planting is finished is a major consideration in the tubeling programme.

Payment for planting is made on a day-acre or piecework basis. As in the planting of nursery stock, the piece work system is generally found to be more efficient. Production on a piecework basis averages 1725 seedlings planted per day, with total planting costs averaging approximately $\$ 21.90$ per thousand. Planters are paid an average of $1.3 \phi$ per tree planted, with average earnings of approximately $\$ 23.00$ per day, plus $4 \%$ vacation allowance. Previous experience indicates that piecework planting should vary, depending on planting conditions, from 1300 to 2500 per day (average 1725). Planting production on a daily rated basis generally equals about $60 \%$ of the above mentioned quantities.

During recent years, the Department has encouraged the piecework or incentive system of payment for planting of both nursery stock and tubed seeddlings. From experience gathered in recent years, the Department has determined that piecework planting when properly organized and supervised results in:

1. a marked increase in production per man-day;

2. a reduction in overall planting time;

3. easier recruitment of better workers;

4. increased quality of planting;

5. increased earnings for planters;

6. a marked reduction in planting costs.

In some cases, it may still be desirable to use an hourly ( $\$ 2.54 /$ hour) or daily rate, but this should only be required on a limited basis, such as for fillin planting where the number of trees planted daily at piecework rates may be insufficient to equal the daily rate. It is necessary to employ crew bosses on an hourly or daily rate, and it is desirable to set the rate sufficiently high to ensure that his earnings are at least equivalent to or greater than the earnings of the pieceworker.

The following instructions relate to crew organization and duties of crew bosses and foreman:

1. crews should be composed of 10 planters, under the supervision of a capable and reliable crew boss, probably a seasonal employee;

2. the planting foreman, who should have several crew bosses responsible to him, should be a member of the regular staff;

3. crew bosses should keep a record of the number of trees planted daily by each member of the crew. This may be averaged over the crew of 10 , if desired;
4. the crew should work as a unit, with fast planters working in one crew and slow planters working in other crews;

5. the crew bosses should turn in their time books to the foreman each night, for a tally of the total trees by planter. The foreman records the total trees planted less any deductions for penalties;

6. the necessary service organization should be set up to ensure that the planters are supplied with trees as required;

7. the trees are counted and recorded by the serviceman, before distribution to the planters and checked with production tallies of the crew bosses daily.

Planting may be carried out from camps, or by planters commuting daily from headquarters. The latter procedure is recommended whenever feasible, because of the high over-head costs presented by camp operations.

Several operating companies are using incentive bonus and piecework systems to improve their planting efficiency on planting operations carried out under authority of Regeneration Agreements. This procedure should be encouraged, provided the necessary supervisory staff can be supplied and adequate standards and controls are maintained.

\section{Results to Date}

In 1966 the Department planted about 17 million tubed seedlings on Crown Lands. This was the first year the new programme was initiated and the results attained were only fair, ranging from good success in some Districts to complete failure in others. Some causes of mortality in tubed seeddlings were frost heaving, dessication, flooding, frost, snow, insect and bird damage. It is now believed that most of these losses can be greatly reduced by growing larger stock, planting tubes flush with the ground, avoiding bare mineral soil and completing planting in August.

Preliminary assessments of the 1968 planting, after one year in the field, indicate an average survival of somewhat better than $70 \%$ which is a considerable improvement over the 1966 planting and compares favourably with the survival of nursery stock. It is expected that the survival and growth rates of tubed seedlings will continue to improve, as we gain more experience in both production and planting procedures.

Although it is too early to assess the full possibilities of the tubed seedling programme, we feel that this method of regenerating forest land will become a useful addition to other regeneration techniques. Flexibility and reduced planting costs over conventional planting are desirable features. A major consideration is the production and availability of planting stock with an undisturbed root system. This enables reasonable survival from summer planting and allows optimum use of available resources. We are aware that several agencies in Canada are presently engaged in container planting and we would be pleased to exchange information on this phase of regeneration work with anyone involved or interested in this programme. 